\title{
Role of Inflammatory Cytokines in Obese and Nonobese Diabetic Children
}

\author{
Enas R. Abdelhamid ${ }^{1}$, Alyaa H. Kamhawy ${ }^{1 \star}$, Hanaa H. Ahmed ${ }^{2}$, Mones M. Abu Shady ${ }^{1}$, Rasha Eladawy ${ }^{3}$, Amr S. Megawer $^{4}$, \\ Yasmine M. Amrousy ${ }^{5}$ \\ ${ }^{1}$ Department of Childhealth, Medical Research Division, National Research Centre, Giza, Egypt; ${ }^{2}$ Department of Hormones, \\ Medical Research Division, National Research Centre, Giza, Egypt; ${ }^{3}$ Department of Pediatric, Faculty of Medicine, Ain Shams \\ University, Cairo, Egypt; ${ }^{4}$ Department of Pediatric, Research Institute of Ophthalmology, Giza, Egypt; ${ }^{5}$ Department Clinical \\ Pathology, Faculty of Medicine, Helwan University, Cairo, Egypt
}

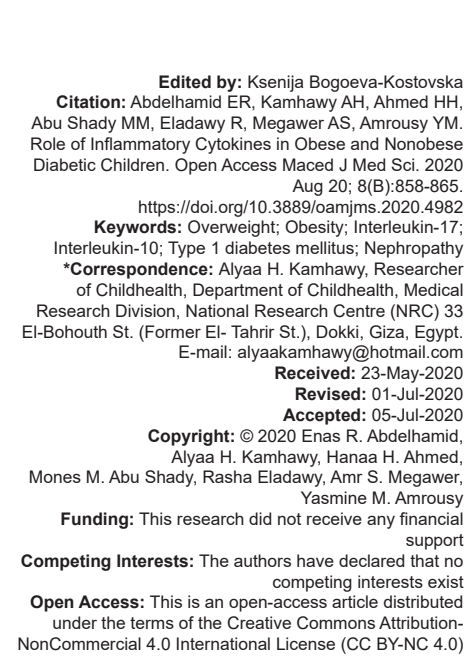

\section{Introduction}

Overweight and obesity in children are growing global health issues. Obesity is defined as an excessive accumulation of fat that occurred due to entertaining a lot of calories than the body can consume. They have emerged as one of the major global health problems. In fact, previous studies have estimated that more than 2 billion adults worldwide are overweight (body mass index $[\mathrm{BMI}] \geq 25 \mathrm{~kg} / \mathrm{m}^{2}$ ), and 671 million of them are clinically obese $\left(\mathrm{BMl} \geq 30 \mathrm{~kg} / \mathrm{m}^{2}\right)$ [1]. Accordingly, it was suggested that more than $51 \%$ of the population all over the world will be obese by 2030 [2].

Excessive weight gain leads to severe complications such as hypertension, diabetes, atherosclerosis, and hyperlipidemia, which have been defined as "metabolic syndrome." However, only half of the obese patients with BMI from 30 to $50 \mathrm{~kg} / \mathrm{m}^{2}$ had metabolic disorders [3].

Type 1 diabetes mellitus (T1DM) is an autoimmune disease characterized as multifactorial disorders attributable to $T$ cell-mediated destruction of the pancreatic $\beta$ cells caused by the interaction between inherited and ecological factors [4]. It accounts for 80-90\% in diabetic children and adolescents [5] and its incidence was 387 million in 2014, and a raise of approximately 205 million new cases are expected to occur by 2035 [6]. Some of the diabetic patients are asymptomatic, particularly in children with absolute insulin insufficiency who may undergo polyphagia, polydipsia, polyuria, blurred vision, and weight loss. Uncontrolled diabetic individuals may cause stupor, coma, and ketoacidosis or nonketotic hyperosmolar 
syndrome that may lead to death [7], DM1 is strongly related to chronic low-grade inflammation, which is largely presented in obese individuals, it is related to the fact that, in obese individuals, visceral white adipose tissue (AT) is characterized by hyperplasic and hypertrophic adipocytes, with infiltration of inflammatory macrophages, endothelial cells activation, and fibrosis. Another important factor is the phenomena called inflammaging, which consists of the positive regulation of the chronic low-grade inflammatory. Thus, high levels of pro-inflammatory cytokines like IL-17 combined with the reduction of anti-inflammatory cytokines, like IL-10, lead to an imbalance in the inflammatory composition of the innate and acquired immune system and have been related to the development and maintenance of several chronic diseases like T1DM [8].

Diabetic nephropathy occurs in $30 \%$ of people with T1DM, mostly in post adolescents. Albumin excretion rate increases until frank albuminuria occur which may result in renal failure [9].

Cytokines are extracellular proteins of low molecular weight that acts as immune response mediators. They perform in highly complex pathways that regulate the inflammatory process, and they are essential to conduct response to the lesion site. Obesity is associated with low-grade chronic inflammation. Indeed, AT in obese individuals are the former site of progressive infiltration by pro-inflammatory immune cells, which, together with increased inflammatory adipokine secretion, induce adipocyte insulin resistance. IL-17 and IL10 cells are part of obese AT infiltrating cells and are likely to be promoted by adipose [3].

Low-grade chronic inflammation and stimulation of the innate immune system are identified to be strongly linked to the pathogenesis of DM [10]. Pro- and antiinflammatory cytokines have been suggested to be implicated in the events of diabetes [11]. Previous reports revealed that definite pro- and/or anti-inflammatory cytokines are able to interfere with insulin-responsive glucose uptake and stimulate insulin resistance [12]. IL-10 and IL-17 have been found to be connected with the pathophysiology of DM1; however, their interplay in the modulation of diabetogenic T-cells remains unknown.

IL-10 plays a central role in regulating immune response and limiting inflammation. IL-10 suppresses inflammation through various mechanisms, including inhibition of the synthesis of pro-inflammatory cytokines such as IL12 and TNF $\alpha$ through suppression of p65 NF-kB and c-Rel activity in macrophages [13]. IL-10 is also important in the downregulation of the release of reactive oxygen species and nitrogen intermediates, regulation of antigen presentation capacity and immune tolerance [14], and suppression of proliferative and cytotoxic T cell responses [15].

IL-17 was discovered as cytotoxic T-lymphocyte associated antigen 8 in 1993 [16].

After 10 years, it was identified that the cellular source of this cytokine is Th17 cells [17].
Th17 cells are likely to play a major role in the propagation of inflammation and in the immunometabolism, which can be easily modified with a hypercaloric diet as it was mentioned before that the hypercaloric diet induces enrichment of pathogenic Th17 cells, in several metabolic organs [18]. However, data obtained from human T1DM studies and mouse models suggest the involvement of Th17 in the pathogenesis of this disease [19]

This study was intended to explore the mechanism behind the role of $\mathrm{IL}-10$ and $\mathrm{IL}-17$ in inflammation associated with obesity in diabetic children. Furthermore, the study was extended to find out the possibility of utilizing these cytokines as early predictors for T1DM complications, particularly nephropathy.

\section{Subjects and Methods}

Between October 2019 and March 2020, 92 diabetic children (T1DM) attending the Unit for Pediatric Diabetes and Endocrinology, Children Hospital, Ain Shams University, were selected for this study. The study group of T1DM children was diagnosed according to the criteria provided by the American Diabetes Association. The parents gave informed consent and children of 10 years of age or older signed their informed consent by themselves after full explanation of the aim of the work, plan of action and blood as well as urine sampling, the protocol of the study was approved by the Ethics Committees for Medical Research of the National Research Centre, Egypt. The diabetic children age ranged between 5 and 15 years were divided into two groups: 34 overweight and obese diabetics (Group 1) and nonobese diabetics (Group 2). All anthropometric parameters have been obtained using standardized equipment and following the recommendations of the International Biological Program [20]. Obesity was considered when BMI exceeded $95^{\text {th }}$ percentile while overweight was considered when BMI was from $85^{\text {th }}$ to $95^{\text {th }}$ percentile and other normal weight diabetic children [21]. Assessment of BMI was done using categories reported by the World Health Organization (WHO) Child Growth Charts Standards for age and sex [22].

Participants were excluded for any of the following reasons: The presence of other chronic or inflammatory disease, drugs or medications (other than insulin), presence of known renal disease or systemic disease, or acute infection at the time of testing.

\section{Laboratory and clinical data}

The background information of subjects such as age, gender, weight, height, daily dose of insulin injection, disease duration, and family history of diabetes was recorded. Furthermore, detailed medical history and physical examination were carried out. Disease 
duration was defined in this study as the day of the initial diagnosis of diabetes to the day of blood collection.

\section{Samples collection for biochemical analysis}

From each child, $5 \mathrm{ml}$ of fasting blood samples were withdrawn; $4 \mathrm{ml}$ were collected in a vacuum tube free from EDTA for separation of serum, and $1 \mathrm{ml}$ was put in another tube with anticoagulant for determination of glycated hemoglobin. Serum samples were separated using a cooling centrifuge $\left(4^{\circ} \mathrm{C}\right)$ at $1800 \times g$ for 10 min and stored at $-20^{\circ} \mathrm{C}$ until analysis. Triglycerides and cholesterol were quantified using colorimetric techniques on Synchron Cx7 (Beckman Instruments Inc., Brea, California, USA) [23]. Glycated hemoglobin was measured in whole blood colorimetrically using a kit obtained from Biosystems (Spain) according to the

According to the manufacturer's protocol, IL-10 and IL-17 were assayed by employing the Human cytokine ELISA set. IL-10 ELISA kit was purchased from SinoGeneClon Biotech Co., Ltd., China, for the quantitative determination of Human IL-10 concentrations, from SinoGeneClon Biotech Co., Ltd., China, for the quantitative determination of Human IL-17 concentrations, Catalog No: SG-10278. For random urinary microalbumin measurement, an early morning midstream urine specimens were used. The cloudy samples were centrifuged before use and the clear supernatants were stored at $-20^{\circ} \mathrm{C}$ until analysis. Microalbumin concentrations were estimated in urine using a Minineph Microalbumin kit based on the nephelometry method on a Minineph nephelometer (AD200) (Birmingham, UK). The diagnosis of nephropathy was established when microalbumin in the urine was more than $30 \mu \mathrm{gldl}$ [25].

\section{Statistical analysis}

Data entry was carried on Excel sheet and statistical analysis was done using the SPSS software program, version 18.0 (SPSS Inc., PASW Statistics for Windows, Version 18.0. Chicago, USA). Chi-square was done for qualitative data that were presented by numbers and percentages. t-test was done for comparison between two means. A simple linear correlation (Pearson's correlation) for quantitative data was also done. $\mathrm{P}$ value was considered statistically significant when $p<0.05$ and considered statistically highly significant when its value was $<0.01$.

\section{Results}

A total number of 92 Egyptian diabetic children were included in this study. The study group method of Roberts et al. [24]. Catalog No: SG-10271. IL-17 ELISA kit was purchased

was divided into two groups: Group 1 (38 overweight and obese diabetic) and Group 2 (52 normal weight diabetic cases). Diabetic cases were further classified according to their glycated hemoglobin ( $\mathrm{HbA} 1 \mathrm{c})$ level into Group A (67 controlled $\mathrm{HbA} 1 \mathrm{c}<8 \%$ ) and Group B (25 uncontrolled $\mathrm{HbA} 1 \mathrm{c}>8 \%$ ) diabetic groups. All children were age- and sex-matched.

The mean age was $9.58 \pm 2.585$ years old in overweight and obese diabetes versus $9.56 \pm 2.377$ years old in normal-weight diabetes with no significant difference between them $(p>0.05)$, as shown in Table 1. The data presented in Table 1 also shows a statistically significant difference between obese and normal-weight diabetic children regarding cholesterol, IL10, IL17, HBA1c, and insulin dose. Meanwhile, there is no significant difference between both groups regarding age, disease duration, or triglyceride level $(p>0.05)$.

Table 1: Comparison between both diabetic groups regarding some clinical and biochemical findings according to BMI

\begin{tabular}{|c|c|c|c|c|}
\hline Items & $\frac{\text { Group } 1}{}$ & Group 2 & t-test & $\mathrm{p}$ \\
\hline Age (years) & $9.58 \pm 2.585$ & $9.56 \pm 2.377$ & 0.045 & 0.964 \\
\hline Disease duration (years) & $6.50 \pm 1.484$ & $6.37 \pm 1.218$ & 0.459 & 0.647 \\
\hline Cholesterol (mg/dL) & $181.63 \pm 22.114$ & $152.57 \pm 15.162$ & 7.482 & $0.000^{\star}$ \\
\hline Triglycerides (mg/dL) & $76.63 \pm 11.034$ & $72.67 \pm 11.384$ & 1.666 & 0.099 \\
\hline IL10 (pg/ml) & $3.608 \pm 0.9763$ & $7.959 \pm 0.9591$ & -21.269 & $0.000^{*}$ \\
\hline IL17 (pg/ml) & $196.947 \pm 21.5825$ & $141.930 \pm 13.8687$ & 14.884 & $0.000^{*}$ \\
\hline HBA1c $(\mathrm{g} \%)$ & $10.182 \pm 2.1145$ & $8.156 \pm 1.5811$ & 5.259 & $0.000^{*}$ \\
\hline Insulin dose (unit/kg/day) & $1.382 \pm 0.3083$ & $1.104 \pm 0.1843$ & 5.400 & $0.000^{*}$ \\
\hline
\end{tabular}

The data depicted in Table 2 shows a statistically significant difference between diabetic children with good and bad glycemic control regarding BMI percentile, cholesterol, IL10, and insulin dose $(p<0.05)$ but there is no significant difference between both groups regarding age, disease duration, TG, or IL17 ( $p>0.05)$.

Table 2: Comparison between the diabetic groups regarding some clinical and biochemical findings according to the glycemic control

\begin{tabular}{|c|c|c|c|c|}
\hline Items & $\begin{array}{l}\text { Group } 1 \\
\text { Mean } \pm \text { SD }\end{array}$ & Group 2 & t-test & $\mathrm{p}$ \\
\hline Age (years) & $9.20 \pm 1.756$ & $9.70 \pm 2.663$ & -0.872 & 0.386 \\
\hline Disease duration (years) & $6.20 \pm 1.323$ & $6.51 \pm 1.330$ & -0.988 & 0.326 \\
\hline BMI centile & $56.72 \pm 19.974$ & $74.10 \pm 22.329$ & -3.414 & $0.001^{*}$ \\
\hline Cholesterol (mg/dL) & $155.80 \pm 18.690$ & $167.85 \pm 24.021$ & -2.263 & $0.026^{*}$ \\
\hline Triglycerides (mg/dL) & $75.84 \pm 13.576$ & $73.73 \pm 10.459$ & 0.791 & 0.431 \\
\hline IL10 (pg/ml) & $7.256 \pm 1.8301$ & $5.754 \pm 2.4148$ & 2.819 & $0.006^{*}$ \\
\hline IL17 (pg/ml) & $155.504 \pm 27.9879$ & $168.069 \pm 33.3187$ & -1.676 & 0.097 \\
\hline Insulin dose (unit/kg/day) & $1.048 \pm 0.1295$ & $1.282 \pm 0.2923$ & -3.855 & $0.000^{*}$ \\
\hline
\end{tabular}

Table 3 shows that diabetic overweight and obese children displayed significantly 3.8 folds more at risk to be bad glycemic control than diabetic children with normal BMI (Table 3).

Table 3: Association between glycemic control and obesity

\begin{tabular}{|c|c|c|c|}
\hline \multirow[t]{2}{*}{ Items } & \multicolumn{2}{|l|}{ Glycemic control } & \multirow[t]{2}{*}{ Total } \\
\hline & $\begin{array}{l}\text { Group A (controlled } \\
\mathrm{HbA} 1 \mathrm{c}<8 \% \text { ) }\end{array}$ & $\begin{array}{l}\text { Group B (uncontrolled } \\
\mathrm{HbA} 1 \mathrm{c}>8 \% \text { ) }\end{array}$ & \\
\hline \multicolumn{4}{|l|}{ Obesity } \\
\hline \multicolumn{4}{|c|}{ Overweight and obese } \\
\hline Count & 33 & 5 & 38 \\
\hline$\%$ within obesity & 86.8 & 13.2 & 100.0 \\
\hline \multicolumn{4}{|l|}{ Normal BMI } \\
\hline Count & 34 & 20 & 54 \\
\hline$\%$ within obesity & 63.0 & 37.0 & 100.0 \\
\hline
\end{tabular}


The data in Table 4 show that overweight and obese diabetic children displayed significantly 15 times more at risk of having nephropathy than diabetic children with normal BMI (Table 4).

Table 4: Association between obesity and diabetic nephropathy

\begin{tabular}{|c|c|c|c|}
\hline \multirow[t]{2}{*}{ Items } & \multicolumn{2}{|c|}{ Nephropathy } & \multirow[t]{2}{*}{ Total } \\
\hline & Yes & No & \\
\hline \multicolumn{4}{|l|}{ BMI } \\
\hline \multicolumn{4}{|c|}{ Overweight and obese } \\
\hline Count & 14 & 24 & 38 \\
\hline$\%$ within obesity & 36.8 & 63.2 & 100.0 \\
\hline \multicolumn{4}{|l|}{ Normal BMI } \\
\hline Count & 2 & 52 & 54 \\
\hline$\%$ within obesity & 3.7 & 96.3 & 100.0 \\
\hline
\end{tabular}

The data presented in Table 5 showed a statistically significant negative correlation between IL10 and IL17, BMI, cholesterol, HBA1c, and insulin dose, while there is a significant positive correlation between IL17 and BMI, cholesterol, and HBA1C.

Table 5: Correlation between different variables in diabetic children

\begin{tabular}{|c|c|c|}
\hline Items & $\mathrm{IL} 10(\mathrm{pg} / \mathrm{ml})$ & IL17 (pg/ml) \\
\hline \multicolumn{3}{|c|}{ Age (years) } \\
\hline $\mathrm{r}$ & -0.036 & -0.060 \\
\hline $\mathrm{p}$ & 0.736 & 0.567 \\
\hline \multicolumn{3}{|c|}{ Disease duration (years) } \\
\hline $\mathrm{r}$ & -0.085 & -0.073 \\
\hline $\mathrm{p}$ & 0.421 & 0.491 \\
\hline \multicolumn{3}{|c|}{ BMI centile } \\
\hline $\mathrm{r}$ & $-0.837^{\star *}$ & $0.742^{\star *}$ \\
\hline $\mathrm{p}$ & 0.000 & 0.000 \\
\hline \multicolumn{3}{|c|}{ Cholesterol (mg/dL) } \\
\hline $\mathrm{r}$ & $-0.667^{\star \star}$ & $0.493^{\star *}$ \\
\hline $\mathrm{p}$ & 0.000 & 0.000 \\
\hline \multicolumn{3}{|c|}{ Triglycerides (mg/dL) } \\
\hline $\mathrm{r}$ & -0.188 & 0.033 \\
\hline $\mathrm{p}$ & 0.072 & 0.755 \\
\hline \multicolumn{3}{|c|}{ IL10 (pg/ml) } \\
\hline $\mathrm{r}$ & 1 & $-0.732^{\star *}$ \\
\hline $\mathrm{p}$ & & 0.000 \\
\hline \multicolumn{3}{|c|}{ IL17 (pg/ml) } \\
\hline $\mathrm{r}$ & $-0.732^{\star *}$ & 1 \\
\hline \multirow{2}{*}{\multicolumn{3}{|c|}{ HBA1c (g\%) }} \\
\hline & & \\
\hline $\mathrm{r}$ & $-0.500^{\star *}$ & $0.400^{\star *}$ \\
\hline $\mathrm{p}$ & 0.000 & 0.000 \\
\hline \multicolumn{3}{|c|}{ Insulin dose (unit/kg/day) } \\
\hline $\mathrm{r}$ & $-0.527^{\star \star}$ & $0.393^{\star *}$ \\
\hline $\mathrm{p}$ & 0.000 & 0.000 \\
\hline
\end{tabular}

Table 6 and Figures 1 and 2 showed that low level of IL 10 and high level of IL 17 were significantly associated with high BMI in diabetic children.

Table 6: Multiple linear regression analysis of factors affecting $\mathrm{BMI}$ in diabetic children

\begin{tabular}{|c|c|c|c|c|c|}
\hline \multirow[t]{2}{*}{ Items } & \multicolumn{2}{|c|}{$\begin{array}{l}\text { Unstandardized } \\
\text { coefficients }\end{array}$} & \multirow{2}{*}{$\begin{array}{l}\text { Standardized } \\
\text { coefficients } \\
\text { Beta }\end{array}$} & \multirow[t]{2}{*}{$\mathrm{t}$} & \multirow[t]{2}{*}{ Sig. } \\
\hline & $\mathrm{B}$ & SE & & & \\
\hline (Constant) & 20.213 & 24.367 & & 0.830 & 0.409 \\
\hline HBA1c $(\mathrm{g} \%)$ & 1.382 & 0.761 & 0.125 & 1.816 & 0.073 \\
\hline IL10 (pg/ml) & -4.655 & 0.971 & -0.478 & -4.795 & $0.000^{*}$ \\
\hline IL17 (pg/ml) & 0.206 & 0.056 & 0.289 & 3.666 & $0.000^{*}$ \\
\hline Cholesterol (mg/dL) & 0.113 & 0.071 & 0.115 & 1.598 & 0.114 \\
\hline Triglycerides (mg/dL) & 0.198 & 0.111 & 0.098 & 1.779 & 0.079 \\
\hline Insulin dose (unit $/ \mathrm{kg} /$ day) & -1.488 & 5.770 & -0.018 & -0.258 & 0.797 \\
\hline
\end{tabular}

Table 7 showed that high HBA1c, low IL 10, and long disease duration are all considered as risk factors of diabetic nephropathy in diabetic children.

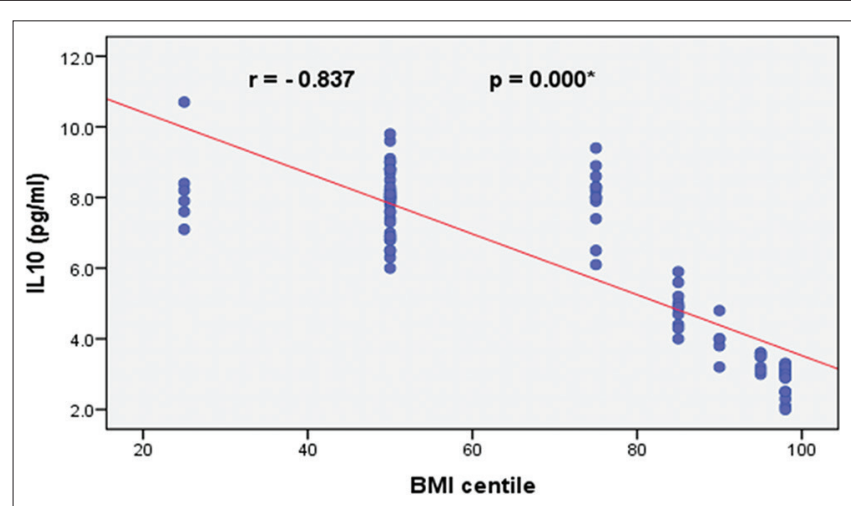

Figure 1: Correlation between body mass index and interleukin-10

\section{Discussion}

Long-term complications of DM1 are secondary to the damaging impacts of the metabolic consequences of insulin deficiency on tissues of different body organs. Maintaining good control of diabetes by preventing prolonged hyperglycemia is essential to avoid developing complications it in later life [9].

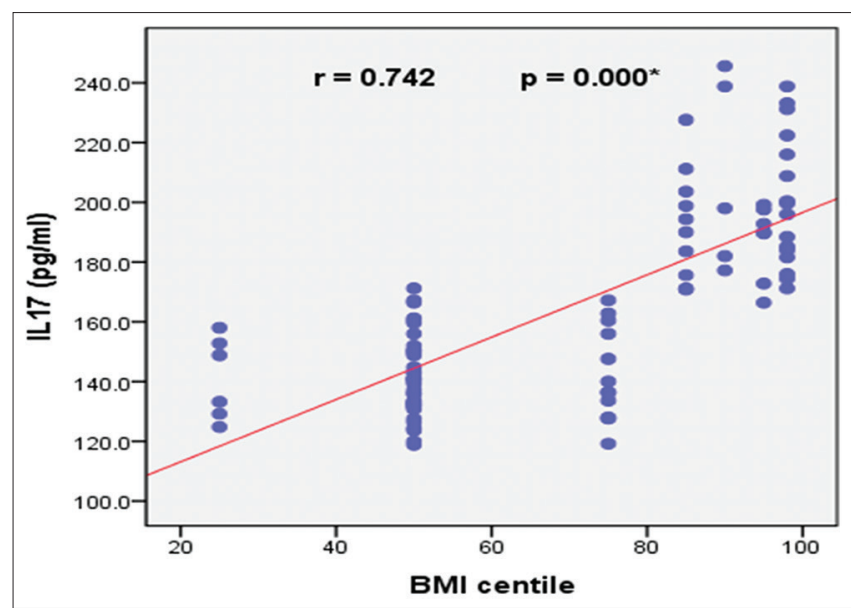

Figure 2: Correlation between body mass index and interleukin-17

Obesity is well known to predispose individuals to metabolic syndrome (MetS). The mechanisms involved in obesity-related pathological processes involve various immune cells, which release IL10 and IL17 [18].

Table 7: Multiple logistic regression analysis of risk factors of diabetic nephropathy

\begin{tabular}{llllll}
\hline Items & $\mathbf{B}$ & Adjusted OR & \multicolumn{2}{c}{$\mathbf{9 5 \%}$ Cl for OR } & Sig. \\
\cline { 5 - 5 } & & & Lower & Upper & \\
\hline HBA1c & 1.161 & 3.192 & 1.193 & 8.543 & $0.021^{*}$ \\
BMI centile & -0.084 & 0.919 & 0.813 & 1.039 & 0.177 \\
IL10 & -1.710 & 0.181 & 0.034 & 0.955 & $0.044^{*}$ \\
IL17 & 0.020 & 1.020 & 0.960 & 1.084 & 0.521 \\
Cholesterol & -0.030 & 0.971 & 0.906 & 1.039 & 0.393 \\
Disduration & 1.377 & 3.963 & 1.089 & 14.418 & $0.037^{*}$ \\
Age & 0.427 & 1.533 & 0.900 & 2.612 & 0.116 \\
Insulin dose & -1.188 & 0.305 & 0.004 & 25.414 & 0.599 \\
Triglycerides & 0.042 & 1.043 & 0.943 & 1.154 & 0.409 \\
Constant & -12.218 & 0.000 & & & 0.344 \\
\hline "p < 0.05 is significant. BMI: Body mass index, HBA1c: Glycated hemoglobin, IL: Interleukin, OR: Odds
\end{tabular}


There is growing evidence linking IL10 and IL17 to obesity [26]. metabolic syndrome (MetS) and cardiovascular disease are also linked to IL10 and IL17 [27].

This research provides relevant information on the influence of body composition on inflammatory and biochemical markers in overweight and obese diabetic and normal weight diabetic children. We demonstrate how body composition interferes with the balance of cytokines, especially IL-10 and IL-17, and how it may exert an effect on the biochemical parameters and risk factors associated with T1DM.

The purpose of this study was to predict if the inflammatory cytokines (IL-17 and IL-10) were beneficial as biomarkers in early screening for obesity and T1DM and to determine the relation of inflammatory cytokines with diabetic complications, especially nephropathy.

Comparison of different variables in both obese and normal-weight groups according to BMI group revealed that serum cholesterol, IL-10, IL-17, HBA1c levels, and insulin dose are the factors showing a significant difference between both groups. And to some extent, the findings of previous researches came in accordance with our conclusion as the study done by Israel et al. [8]. We next performed multiple linear regression analysis to predict variants that are independently associated with BMI and we found that IL-10 and IL-17 concentration are strongly associated with BMI. This study showed that IL-10 concentration is negatively correlated with blood cholesterol but not triglycerides. Moreover, this comes in agreement with a study done by Jung and Choi, who stated that IL-10 exerts essential control over the biochemical parameters such as LDL, VLDL, HDL, triglycerides, and glucose [28]. While on the contrast of our findings Jung and Choi reported that such a correlation pattern is not detected in overweight women, in whom IL-10 showed a negative correlation only with total cholesterol and LDL.

In the current study, the overweight and obese diabetic children had a low level of IL-10 and this agrees with a study done by Jung et al. [29], in which when compared overweight and obese with their normalweight counterparts, overweight and obese children had lower serum IL-10. In contrast, a study done by Pereira et al. revealed that obese women have higher serum concentrations of IL-10 as feedback generated from the elevated expression of pro-inflammatory cytokines as a result of obesity [30]. However, that increase is not sufficient to govern the development of the pro-inflammatory profile [31].

Many other studies investigating IL10 in children and young adolescents with obesity have yielded conflicting results [32], [33], [34], [35]. Another study, included 80 obese and 80 nonobese Egyptian children, agreed with our results as these authors stated that serum levels of IL-10 are significantly lower in the former group [32]. This could be explained by a study done by Lauridsen et al., gave accentual evidence concerning this as they demonstrated that in the prefrontal cortex of neurologically and psychiatrically healthy humans, a gradual increase in BMI is associated with discrete signs of altered gene expression, that leads to downregulation of mRNA expression of the anti-inflammatory cytokine IL-10 [33].

However, this comes in conflict with Calcaterra et al. in a study, including 70 severely obese and 30 normal-weight children aged 11.46 \pm 3.42 years old, Calcaterra et al. stated that serum IL-10 concentrations are higher in severely obese children compared to normal weight [34]. Tam et al. recorded no differences in IL-10 concentration between normal and overweight children at 8 years old; however, at 15 years old, serum IL-10 is elevated in overweight and obese girls when compared to normal weight girls of the same age [35].

The study done by Chang et al. suggested that the effect of obesity on IL-10 serum concentration varies with age, but in this current study, we did not find a correlation between IL-10 and IL-17 and age neither in the obese group nor in the normal-weight group [29].

In the present study, IL17 is significantly increased in overweight and obese diabetic compared to normal weight diabetic and this agrees with a study of Sumarac-Dumanovic who observed significant enhancement in circulating IL-17 and IL-23 cytokines in obese as compared with lean individuals [36]. The relationship between obesity and serum level of IL-17 has been further demonstrated in a sheep model, where maternal obesity provoked an inflammatory state in the fetal intestine, with increased levels of inflammatory cytokines, particularly IL-17 [37]. Infiltrating IL-17+-secreting cells have also been noticed more abundant, in obese versus lean AT, and in visceral versus subcutaneous AT [38]. Dalmas et al. have shown that single populations of IL-17+ IL-22and IL-17-IL-22+ and double populations of IL-17+ IL-22+ CD4+ T cells are highly induced in the mucosal tissues of obese subjects, as compared with non-obese [39]. Supporting the implication of IL-17 in the MetS, the levels of IL-17 expression in liver or muscle were shown to correlate with insulin resistance [38], and the blockade of IL-17 resulted in the decrease of hepatic inflammation in the non-alcoholic steatohepatitis syndrome (NASH) [40].

This current study also demonstrated that proinflammatory cytokine IL-17 and the anti-inflammatory IL-10 are significantly negatively correlated and this matches the findings of Winer et al. which showed that in obese rats the increase of IL- 6 due to obesity causes maturation of Th17 and secretion of IL-17which inhibits IL-10 secretion and Treg development and this, in turn, intensified inflammation in the body [41].

Comparing the two groups of diabetics according to their glycemic control level using $\mathrm{HbA} 1 \mathrm{c}$ $8 \%$ as a cutoff (controlled [<8\%] and uncontrolled [>8\%] 
diabetic group), a significant difference between good and bad glycemic control has been found regarding BMI, IL10, cholesterol and insulin dose. Diabetic overweight and obese children were significantly 3.8 folds more at risk to be bad glycemic control than diabetic children with normal BMI. This result comes in line with that of El-Wakeel et al.'s study [42]; this strong association was confirmed by many other studies [8], [18].

The current study showed that overweight and obese diabetic children are significantly at higher risk of having nephropathy than diabetic children with normal BMI. This coincides with the study done by $\mathrm{Zu}$ et al. which explained this as obesity is associated with hyperleptinemia, which contributes to a decline in eGFR and pathological processes [43]. Changwei et al. did not agree with this result in their study, where 481 patients with nephropathy were finally enrolled in the study. There was no significant difference in clinical and pathological characteristics among the four-group patients categorized by BMI. After matching with propensity scores, no significant correlation between BMI and renal outcomes was seen [44]. These findings spotlight the effect of impaired control of hyperglycemia and $\mathrm{BMI}$ on the risk of premature development of complications in the pediatric diabetic population. There are several limitations in our study; the cross-sectional nature of the current study and the relative small sample size are the common limitations of the study. However, in the light of data documented by the results of the present study, we put forward the evidence that high serum IL17 and lower IL10 levels in type 1 diabetic children together with obesity might be collateral to deterioration in diabetic cases and more emerging of diabetic complications as nephropathy.

\section{Conclusion}

This study proved that overweight and obesity in children T1DM are associated with low serum IL-10 concentration and high serum IL-17. The changes in these interleukins in overweight and obese diabetic children may further implicate to the inflammatory environment associated with obesity. The relationship between IL-10/IL-17 can be applied as a good marker for the inflammatory state, and we encourage further studies with a large sample size to confirm this hypothesis. This study is considered as innovative and relevant research in children population showing that serum IL-10 and IL-17 levels can be served as predictors of obesity and diabetes-associated complications.

\section{Acknowledgment}

We would like to thank the children and families who donated blood and urine samples to accomplish this research. Furthermore, we are greatly appreciated the teamwork of El Demerdash Hospital Ain Shams University for help and assistance.

\section{References}

1. Roberto CA, Swinburn B, Hawkes C, Huang TT, Costa SA Ashe $\mathrm{M}$, et al. Patchy progress on obesity prevention: Emerging examples, entrenched barriers, and new thinking. Lancet 2015;385(9985):2400-9. https://doi.org/10.1016/ s0140-6736(14)61744-x

PMid:25703111

2. Yuan L, Hajifathalian K, Ezzati M, Woodward M, Rimm EB, Danaei G. Metabolic mediators of the effects of body-mass index, overweight, and obesity on coronary heart disease and stroke: A pooled analysis of 97 prospective cohorts with 1.8 million participants. Lancet 2014;383(9921):970-83. https://doi. org/10.1016/s0140-6736(13)61836-x

PMid:24269108

3. El Wakeel MA, El-Kassas GM, Kamhawy AH, Galal EM, Nassar MS, Hammad EM, et al. Serum apelin and obesityrelated complications in Egyptian children. Open Access Maced J Med Sci 2018;6(8):1354. https://doi.org/10.3889/ oamjms.2018.312

PMid:30159056

4. Al-Terehi M, Ghaleb R, Al-Oubaidy SA, Al-Saadi AH, Zaidan HK Study TNF- $\alpha$ gene polymorphism in type 1 diabetic patients using amplification refectory mutation system (ARMS) technique. J Chem Pharm Sci 2016;9(3):1107-10.

5. Dabelea D, Mayer-Davis EJ, Saydah S, Imperatore G, Linder B, Divers $\mathrm{J}$, et al. Prevalence of Type 1 and Type 2 diabetes among children and adolescents from 2001 to 2009. JAMA 2014;311(17):1778-86. https://doi.org/10.1001/jama.2014.3201 PMid:24794371

6. International Diabetes Federation. IDF Diabetes Atlas. $7^{\text {th }}$ ed. Brussels, Belgium: International Diabetes Federation; 2015.

7. Galtier F. Definition, epidemiology, risk factors. Diabetes Metab 2010;36(6 Pt 2):628-51. https://doi.org/10.1016/j. diabet.2010.11.014

PMid:21163426

8. Ribeiro IS, Pereira ÍS, Santos DP, Lopes DS, Prado AO Calado SP, et al. Association between body composition and inflammation: A central role of IL-17 and IL-10 in diabetic and hypertensive elderly women. Exp Gerontol 2019;127:110734. https://doi.org/10.1016/j.exger.2019.110734 PMid:31518664

9. Sabry RN, El Wakeel MA, El-Kassas GM, Amer AF, E Batal WH, El-Zayat SR, et al. Serum apelin: A new marker of early atherosclerosis in children with Type 1 diabetes mellitus. Open Access Maced J Med Sci 2018;6(4):613. https://doi. org/10.3889/oamjms.2018.144 PMid:29731925

10. Navarro-Gonzalez JF, Mora-Fernandez C. The role of inflammatory cytokines in diabetic nephropathy. J Am 
Soc Nephrol 2008;19(3):433-42. https://doi.org/10.1681/ asn. 2007091048

PMid:18256353

11. Banerjee M, Saxena M. Genetic polymorphisms of cytokine genes in Type 2 diabetes mellitus. World J Diabetes 2014;5(4):493. https://doi.org/10.4239/wjd.v5.i4.493 PMid:25126395

12. Agrawal NK, Kant S. Targeting inflammation in diabetes: Newer therapeutic options. World J Diabetes 2014;5(5):697. https://doi. org/10.4239/wjd.v5.i5.697

PMid:25317247

13. Rahim SS, Khan N, Boddupalli CS, Hasnain SE Mukhopadhyay S. Interleukin-10 (IL-10) mediated suppression of IL-12 production in RAW 264.7 cells also involves c-rel transcription factor. Immunology 2005;114(3):313-21. https:// doi.org/10.1111/j.1365-2567.2005.02107.x

PMid:15720433

14. Vasu C, Gorla SR, Prabhakar BS, Holterman MJ. Targeted engagement of CTLA-4 prevents autoimmune thyroiditis. Int Immunol 2003;15(5):641-54. https://doi.org/10.1093/intimm/ dxg061

PMid:12697664

15. Couper KN, Blount DG, Riley EM. IL-10: The master regulator of immunity to infection. J Immunol 2008;180(9):5771-7. https:// doi.org/10.4049/jimmunol.180.9.5771 PMid:18424693

16. Ye $\mathrm{P}$, Rodriguez $\mathrm{FH}$, Kanaly $\mathrm{S}$, Stocking $\mathrm{KL}$, Schurr J, Schwarzenberger $\mathrm{P}$, et al. Requirement of interleukin 17 receptor signaling for lung CXC chemokine and granulocyte colony-stimulating factor expression, neutrophil recruitment, and host defense. J Exp Med 2001;194(4):519-28. https://doi. org/10.1084/jem.194.4.519

PMid: 11514607

17. Ashaat EA, Taman KH, Kholoussi N, El Ruby MO, Zaki ME, El Wakeel MA, et al. Altered adaptive cellular immune function in a group of Egyptian children with autism. J Clin Diagn Res 2017;11(10):SC14-7. https://doi.org/10.7860/ jcdr/2017/28124.10782

18. Patel SA, Dave MA, Bliss SA, Giec-Ujda AB, Bryan M, Pliner LF, et al. Treg/Th17 polarization by distinct subsets of breast cancer cells is dictated by the interaction with mesenchymal stem cells. J Cancer Stem Cell Res 2014;2014(2):e1003. https://doi. org/10.14343/jcscr.2014.2e1003

PMid:25705705

19. Marwaha AK, Crome SQ, Panagiotopoulos C, Berg KB, Qin H, Ouyang $Q$, et al. Cutting edge: Increased II-17 secreting $T$ cells in children with new-onset Type 1 diabetes. J Immunol 2010;185(7):3814-8. https://doi.org/10.4049/jimmunol.1001860 PMid:20810982

20. Abdelhamid ER, Kamhawy AH, Ahmed HH, Shady MM, Fathy A, Fahmy RF. Association of cord blood des-acyl ghrelin with apgar score and anthropometric measures in relation to its maternal one. Biomed Pharmacol J 2019;12(3):1147-54. https:// doi.org/10.13005/bpj/1743

21. Shehata MH, Elkayat HA, Hanna AN, El-Khiyat ZA, Kamel IH, Kamhawy $\mathrm{AH}$. Study of retinol and the retinol binding protein 4 in cases of overweight and obese Adolescents. Res J Pharm Biol Chem Sci 2016;7(6):1165-75

22. World Health Organization. Software for Assessing Growth of the Worlds Children and Adolescents. Who Antro Plus for Personal Computers Manual. Geneva: World Health Organization; 2009.

23. Friedewald WT, Levy RI, Fredrickson DS. Estimation of the concentration of low-density lipoprotein cholesterol in plasma, without use of the preparative ultracentrifuge. Clin Chem 1972;18(6):499-502. https://doi.org/10.1093/clinchem/18.6.499
PMid:4337382

24. Roberts WL, De BK, Brown D, Hanbury CM, Hoyer JD, John WG, et al. Effects of hemoglobin $\mathrm{C}$ and $\mathrm{S}$ traits on eight glycohemoglobin methods. Clin Chem 2002;48(2):383-5. https://doi.org/10.1093/clinchem/48.2.383 PMid:11805029

25. Showell PJ, Matters DJ, Long JM, Carr-Smith HD, Bradwell AR. Evaluation of latex- enhanced nephelometric reagents for measuring free immunoglobulin light-chains on a modified MININEPHTM. Clin Chem, 2002;48(6):A22.

26. Stoppa-Vaucher S, Dirlewanger MA, Meier CA, De Moerloose P, Reber G, Roux-Lombard P, et al. Inflammatory and prothrombotic states in obese children of European descent. Obesity 2012;20(8):1662-8. https://doi.org/10.1038/ oby. 2012.85

PMid:22484367

27. El Kassas GM, Shehata MA, El Wakeel MA, Amer AF, Elzaree FA, Darwish MK, et al. Role of procalcitonin as an inflammatory marker in a sample of Egyptian children with simple obesity. Open Access Maced J Med Sci 2018;6(8):1349. https://doi.org/10.3889/oamjms.2018.323

PMid:30159055

28. Jung U, Choi MS. Obesity and its metabolic complications: The role of adipokines and the relationship between obesity, inflammation, insulin resistance, dyslipidemia and nonalcoholic fatty liver disease. Int J Mol Sci 2014;15:6184-223. https://doi. org/10.3390/ijms 15046184

PMid:24733068

29. Chang JS, Chang CC, Chien EY, Lin SS, Cheng-Shiuan T, Bai $\mathrm{CH}$, et al. Association between interleukin $1 \beta$ and interleukin 10 concentrations: A cross-sectional study in young adolescents in Taiwan. BMC Pediatr 2013;13(1):123. https://doi. org/10.1186/1471-2431-13-123

PMid:23941335

30. Pereira S, Teixeira L, Aguilar E, Oliveira M, Savassi-Rocha A, Pelaez JN, et al. Modulation of adipose tissue inflammation by FOXP3+ Treg cells, IL-10, and TGF- $\beta$ in metabolically healthy class III obese individuals. Nutrition 2014;30(7-8):784-90. https://doi.org/10.1016/j.nut.2013.11.023

PMid:24984993

31. Esposito K, Pontillo A, Giugliano F, Giugliano G, Marfella R, Nicoletti $G$, et al. Association of low interleukin-10 levels with the metabolic syndrome in obese women. J Clin Endocrinol Metab 2003;88(3):1055-8. https://doi.org/10.1210/jc.2002-021437 PMid:12629085

32. El Wakeel MA, El-Kassas GM, Hashem SA, Abouelnaga MW, Elzaree FA, Hassan M, et al. Potential role of oxidative stress in childhood obesity and its relation to inflammation. Biosci Res 2018;15(4):3791-9

33. Lauridsen JK, Olesen RH, Vendelbo J, Hyde TM, Kleinman JE, Bibby BM, et al. High BMl levels associate with reduced mRNA expression of IL10 and increased mRNA expression of iNOS (NOS2) in human frontal cortex. Transl Psychiatry 2017;7(2):e1044. https://doi.org/10.1038/tp.2016.259 PMid:28244985

34. Calcaterra V, De Amici M, Klersy C, Torre C, Brizzi V, Scaglia F, et al. Adiponectin, IL-10 and metabolic syndrome in obese children and adolescents. Acta Biomed 2009;80(2):117-23.

35. Tam CS, Garnett SP, Cowell CT, Heilbronn LK, Lee JW, Wong M, et al. IL-6, IL-8 and IL-10 levels in healthy weight and overweight children. Horm Res Paediatr 2010;73(2):128-34. https://doi. org/10.1159/000277632 PMid:20190550

36. Sumarac-Dumanovic M, Stevanovic D, Ljubic A, Jorga J, Simic M, Stamenkovic-Pejkovic D, et al. Increased activity of 
interleukin-23/interleukin-17 proinflammatory axis in obese women. Int J Obes 2009;33(1):151-6. https://doi.org/10.1038/ ijo.2008.216

PMid:18982006

37. Yan X, Huang Y, Wang H, Du M, Hess BW, Ford SP, et al. Maternal obesity induces sustained inflammation in both fetal and offspring large intestine of sheep. Inflamm Bowel Dis 2011;17(7):1513-22. https://doi.org/10.1002/ibd.21539 PMid:21674707

38. Fabbrini E, Cella M, Mccartney SA, Fuchs A, Abumrad NA, Pietka TA, et al. Association between specific adipose tissue CD4+ T-cell populations and insulin resistance in obese individuals. Gastroenterology 2013;145(2):366-74. https://doi. org/10.1053/j.gastro.2013.04.010

PMid:23597726

39. Dalmas E, Venteclef N, Caer C, Poitou C, Cremer I, AronWisnewsky J, et al. T cell derived IL-22 amplifies IL-1 $\beta$ driven inflammation in human adipose tissue: Relevance to obesity and Type 2 diabetes. Diabetes 2014;63(6):1966-77. https://doi. org/10.2337/db13-1511 PMid:24520123

40. Tang Y, Bian Z, Zhao L, LiuY, Liang S, Wang Q, et al. Interleukin-17 exacerbates hepatic steatosis and inflammation in non-alcoholic fatty liver disease. Clin Exp Immunol 2011;166(2):281-90. https://doi.org/10.1111/j.1365-2249.2011.04471.x

PMid:21985374

41. Winer S, Paltser G, Chan Y, Tsui H, Engleman E, Winer D, et al. Obesity predisposes to Th17 bias. Eur J Immunol 2009;39(9):2629-35. https://doi.org/10.1002/eji.200838893 PMid:19662632

42. El Wakeel MA, Abou-El-Asrar MO, El-kassas GM, Elabd MA, Zeid DA, Sabry RN, et al. Urinary markers of oxidative DNA damage in Type 1 diabetic children: Relation to microvascular complications. Asian J Pharm Clin Res 2017;10(10):318-22. https://doi.org/10.22159/ajpcr.2017.v10i10.18930

43. Zhu Q, Scherer PE. Immunologic and endocrine functions of adipose tissue: Implications for kidney disease. Nat Rev Nephrol 2018;14(2):105-20. https://doi.org/10.1038/nrneph.2017.157 PMid:29199276

44. Wu C, Wang AY, Li G, Wang L. Association of high body mass index with development of interstitial fibrosis in patients with IgA nephropathy. BMC Nephrol 2018;19(1):381. https://doi. org/10.1186/s12882-018-1164-2

PMid:30594167 